\title{
Evaluation of the Multi-Chambered Treatment Train, a Retrofit Water-Quality Management Device
}

By Steven R. Corsi, Steven R. Greb, Roger T. Bannerman, and Robert E. Pitt

U.S. GEOLOGICAL SURVEY

Open-File Report 99-270

Prepared in cooperation with the

WISCONSIN DEPARTMENT OF NATURAL RESOURCES

Middleton, Wisconsin

1999

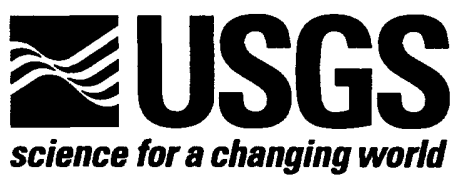




\title{
U.S. DEPARTMENT OF THE INTERIOR BRUCE BABBITT, Secretary
}

\author{
U.S. GEOLOGICAL SURVEY \\ Charles G. Groat, Director
}

Any use of trade, product, or firm names is for descriptive purposes only and does not imply endorsement by the U.S. Government.

\section{District Chief}

U.S. Geological Survey

8505 Research Way

Middleton, WI 53562-3586
U.S. Geological Survey

Branch of Information Services

Box 25286

Denver, CO 80225-0286 


\section{CONTENTS}

Abstract

Introduction

Purpose and scope

Acknowledgments

Study description.

Design of the Multi-Chambered Treatment Train

Site description

Sampling design

Evaluation of Multi-Chambered Treatment Train efficiency

Water quantity.....

Concentration summary statistics ..

Water-quality characteristics

Major ions

Nutrients.

Metals

Polycyclic aromatic hydrocarbons...

Microtox results

Particle-size distribution

Summary

References cited.

Appendixes:

1. Concentrations and other measurements of monitored water-quality characteristics in influent and effluent to the Multi-Chambered Treatment Train at Ruby Street garage in Milwaukee, Wis.

2. Loads and removal efficiencies of monitored constituents in the influent and effluent to the Multi-Chambered Treatment Train at Ruby Street Garage in Milwaukee, Wis.

3. Results from Microtox analyses of influent and effluent samples at the Multi-Chambered Treatment Train at Ruby Street Garage in Milwaukee, Wis.

\section{FIGURES}

1. Cross-sectional view of the Multi-Chambered Treatment Train device, showing the two sampling locations in Milwaukee, Wis.

2. Cumulative rainfall distributions for the study period and historical rainfall records (1948-92) for Milwaukee, Wis.

3. Total influent and effluent loads for volatile suspended solids, total suspended solids, and total dissolved solids accumulated over the entire rating period at the Multi-Chambered Treatment Train in Milwaukee, Wis.

4. Event-mean concentrations of chloride in influent and effluent for the 15 monitored storms, Multi-Chambered Treatment Train study, in Milwaukee, Wis.

5. Event-mean concentrations of ammonium in influent and effluent for the 15 monitored storms, Multi-Chambered Treatment Train study, in Milwaukee, Wis.

6. Average influent and effluent particle-size distributions for the 15 monitored storms in the Multi-Chambered Treatment Train, in Milwaukee, Wis.

\section{TABLES}

1. Aggregate water-quality characteristics and inorganic constituents list analyzed for Multi-Chambered Treatment Train study, Milwaukee, Wis.

2. Organic constituents analyzed for Multi-Chambered Treatment Train study, Milwaukee, Wis.

3. Inorganic influent and effluent minimum, maximum, and median event-mean concentration values for the monitored storms $(\mathrm{n}=15)$ at the Multi-Chambered Treatment Train in Milwaukee, Wis.

4. Dissolved and total influent minimum, maximum, and median event-mean concentrations of polycyclic aromatic hydrocarbons for the monitored storms $(n=15)$ at the Multi-Chambered Treatment Train in Milwaukee, Wis 


\section{CONVERSION FACTORS AND ABBREVIATED WATER-QUALITY UNITS}

\begin{tabular}{|c|c|c|}
\hline Multiply & By & To Obtain \\
\hline centimeter $(\mathrm{cm})$ & 0.394 & inch \\
\hline meter $(\mathrm{m})$ & 3.28 & foot \\
\hline $\operatorname{meters}^{2}\left(\mathrm{~m}^{2}\right)$ & 10.76 & feet $^{2}$ \\
\hline meters ${ }^{3}\left(\mathrm{~m}^{3}\right)$ & 35.31 & feet $^{3}$ \\
\hline liter $(\mathrm{L})$ & 0.2642 & gallon \\
\hline gram & $2.20 \times 10^{-3}$ & pound \\
\hline kilogram (kg) & 2.20 & pound \\
\hline
\end{tabular}

Abbreviated water-quality units used in this report: Chemical concentrations and water temperature are given in metric units. Chemical concentration is given in milligrams per liter $(\mathrm{mg} / \mathrm{L})$ or micrograms per liter $(\mu \mathrm{g} / \mathrm{L})$. Milligrams per liter is a unit expressing the concentration of chemical constituents in solution as weight (milligrams) of solute per unit volume (liter) of water. One thousand micrograms per liter is equivalent to one milligram per liter. For concentrations less than $7,000 \mathrm{mg} / \mathrm{L}$, the numerical value is the same as for concentrations in parts per million. Other units of measurement used in this report are microsiemens per centimeter at $25^{\circ} \mathrm{Celsius}(\mu \mathrm{S} / \mathrm{cm})$ and micrometers $(\mu \mathrm{m})$. 


\title{
Evaluation of the Multi-Chambered Treatment Train, a Retrofit Water-Quality Management Device
}

\author{
By Steven R. Corsi ${ }^{1}$, Steven R. Greb ${ }^{2}$, Roger T. Bannerman ${ }^{2}$, and Robert E. Pitt ${ }^{3}$
}

\section{Abstract}

This paper presents the results of an evaluation of the benefits and efficiencies of a device called the Multi-Chambered Treatment Train (MCTT), which was installed below the pavement surface at a municipal maintenance garage and parking facility in Milwaukee, Wisconsin. Flowweighted water samples were collected at the inlet and outlet of the device during 15 storms, and the efficiency of the device was based on reductions in the loads of 68 chemical constituents and organic compounds. High reduction efficiencies were achieved for all particulate-associated constituents, including total suspended solids ( 98 percent), total phosphorus (88 percent), and total recoverable zinc (91 percent). Reduction rates for dissolved fractions of the constituents were substantial, but somewhat lower (dissolved solids, 13 percent; dissolved phosphorus, 78 percent; dissolved zinc, 68 percent). The total dissolved solids load, which originated from roadsalt storage, was more than four times the total suspended solids load. No appreciable difference was detected between particle-size distributions in inflow and outflow samples.

\section{INTRODUCTION}

The implementation and installation of water-quality best management practices (BMP's) in developed urban areas is problematic. A landscape composed of buildings and pavement presents little opportunity for placement of new BMP's. To overcome this obstacle of limited space, new retrofit BMP technologies are emerging that use underground space, and thus do not disrupt current above-ground land uses. One such device, called the Multi-Chambered Treatment Train (MCTT), uses aeration, settling, filtration, sorption, and ion exchange to provide a high level of treatment of stormwater runoff (Pitt and others, 1997). Underground retrofitted BMP's have two additional advantages. First, they are effective at targeting source areas that generate large pollutant loads, such as maintenance yards and busy parking lots. Second, they provide a viable alternative where space limitations preclude the use of larger open BMP's such as wet detention ponds.

As part of an ongoing program of urban waterquality research in Wisconsin, the U.S. Geological Survey (USGS), in cooperation with the Wisconsin Department of Natural Resources, evaluated the water-quality benefits of a newly constructed MCTT. The primary objective of this project was to design and install a MCTT at a municipal maintenance yard and measure the pollutant reduction achieved by this device. The purpose of this project was to provide Wisconsin's urban land managers with additional information about the MCTT with which to make decisions on the implementation of BMP's.

\section{Purpose and Scope}

This report describes the methods of the Milwaukee MCTT study and presents the results of the USGS and WDNR evaluation. Detailed data on selected waterquality properties and constituents, including concentrations, loads, toxicities, and efficiencies of removal by the MCTT, are listed in appendixes.

\section{Acknowledgments}

Additional support for the construction of the MCTT and subsequent evaluation work was provided by the U.S. Environmental Protection Agency (Region V, Section 319 funds), and the City of Milwaukee. The authors thank Timothy Thur of the City of Milwaukee for providing the site and facilities support and Thomas Davenport, USEPA Region V project officer for program support.

\footnotetext{
${ }^{1}$ U.S. Geological Survey, Middleton, Wisconsin.

${ }^{2}$ Wisconsin Department of Natural Resources, Madison, Wisconsin.

${ }^{3}$ Department of Civil and Environmental Engineering, University of Alabama at Birmingham.
} 


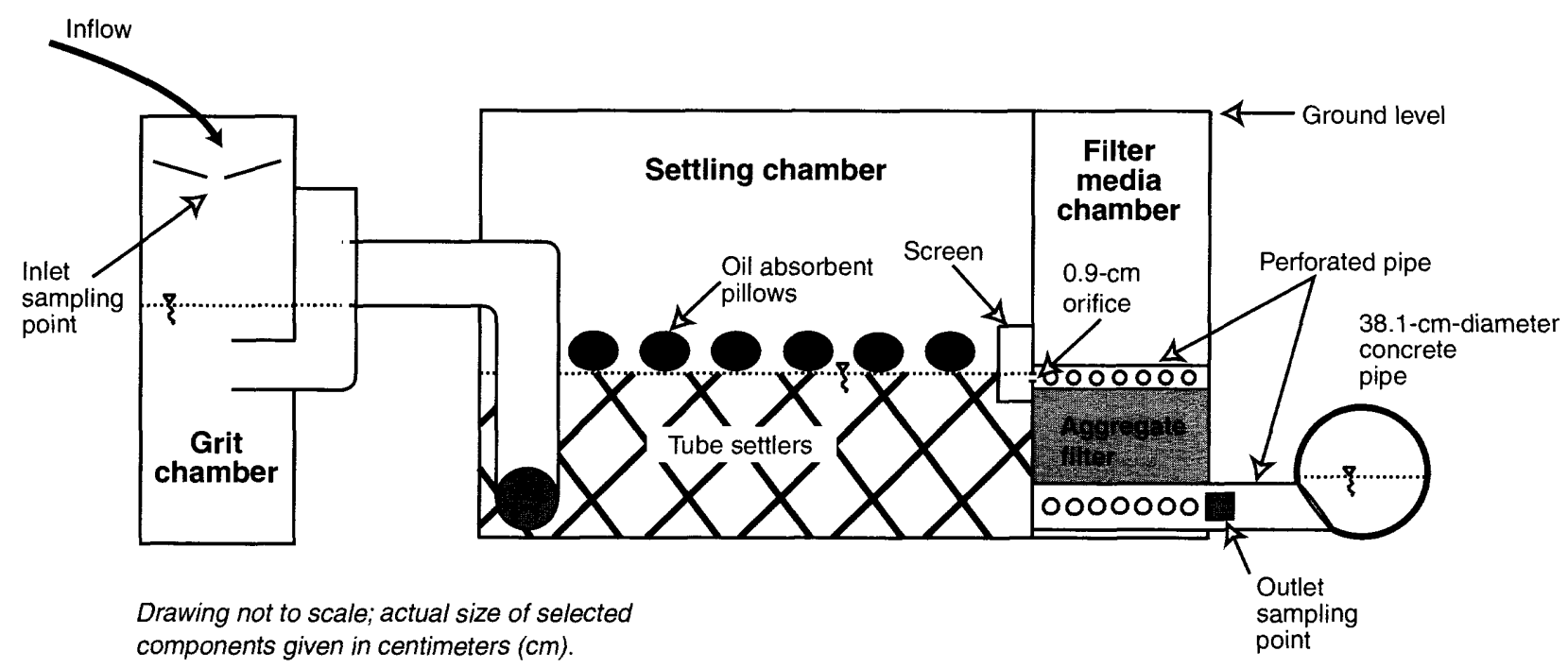

Figure 1. Cross-sectional view of the Multi-Chambered Treatment Train device, showing the two sampling locations in Milwaukee, Wis.

\section{STUDY DESCRIPTION}

\section{Design of the Multi-Chambered Treatment Train}

The MCTT consists of three components: a grit chamber, a settling chamber, and a filter media chamber (fig. 1). The 1.22-m-diameter grit chamber or catch basin removes the larger sized particles in runoff from the contributing area. In addition, a mesh bag of column packing balls suspended in the grit chamber enhances aeration and removal of highly volatile components (this component was not used for the MCTT in this project). The second chamber, where most of the settling takes place, contains inclined tube settlers that increase removal of solids by reducing the distance that particles must fall. The modular tubes are slanted at 60 degrees, so particles are not required to fall the full depth of the tank. As the water flows through the tubes, particles settle on the tube walls. Eventually, built-up material on the tube walls sloughs off and collects in the bottom of the tank, where it is periodically pumped out. The chamber also contains absorbent pillows that remove floatable hydrocarbons. Stormwater fills the tank and then slowly drains to the final chamber by way of a $0.9-\mathrm{cm}$ orifice. This restricted outlet increases water-retention time in the settling tank ( 24 hours when filled completely) and enhances the particle settling. The third chamber, called the filter media chamber, con- tains a mixed media of sand, peat, and activated carbon supported by filter fabric and is designed to remove fine particles, along with some dissolved constituents by means of sorption and ion exchange. Water exits this chamber through a perforated pipe underlying the filter media and flows directly into the existing storm sewer.

The second and third chambers at the study site were constructed from a single partitioned concrete box ( $3.0 \mathrm{~m}$ wide $\times 4.6 \mathrm{~m}$ long $\times 1.5 \mathrm{~m}$ high). The capacity of the settling chamber is $21 \mathrm{~m}^{3}$, although the height of the orifice results in a dead-storage capacity of $10.5 \mathrm{~m}^{3}$, leaving the actual storm-volume capacity at $10.5 \mathrm{~m}^{3}$. Once this capacity is reached, any additional water backs up on the parking-lot surface, eventually spilling over to an adjacent storm-sewer inlet.

Manhole covers were placed in the top of the settling and filter media chambers for access and maintenance purposes. According to design and operation specifications, the unit should be inspected every 6 months to ensure all chambers are operational. The maintenance requirements are somewhat site specific, although the catch basin and settling chambers should be cleaned every 6-12 months and the filter media should be replaced every $3-5$ years.

\section{Site Description}

The site chosen for this project was a municipal maintenance garage and parking facility in Milwaukee, 
Wis. The site is used heavily by garbage trucks, plows, and other large road equipment. The garage, originally built in 1948, is surrounded by a large parking area composed mainly of aged asphalt with some concrete pavement. Given the nature of the parking lot's activities, it is common for oily deposits, yard waste, sand, and salt to accumulate on the pavement surface. Runoff water from the parking area drains into the storm-sewer system through several storm grates/catch-basin inlets. The MCTT device was installed below the pavement surface and placed in line between one of the catch basins and the existing storm-sewer pipe. Because of the finite capacity of the MCTT and the slow draining of the settling chamber, the unit was expected to become surcharged when rainfalls exceeded $1.26 \mathrm{~cm}$, but an overestimation of the runoff area draining to the MCTT led to an overdesign of the device. Consequently, the device can actually hold water from a $2.5 \mathrm{~cm}$ rainfall without being surcharged (the surface area draining to this device is approximately $426 \mathrm{~m}^{2}$ ).

\section{Sampling Design}

The evaluation of the installed MCTT device was based on results of chemical analyses of flow-weighted samples collected during 15 storms at two locations, the inlet and outlet of the device.

The 15 storms (events) were monitored as three separate groups. The first group consisted of four consecutive events, the second was five consecutive events, and the third was six consecutive events. This was done for two reasons: first, because the settling tank has some permanent storage, monitoring individual events would not allow for direct comparison of influent and effluent from the same event, and second, technical difficulties two times during the monitoring period prevented the sampling of 15 consecutive events.

Flow into the device was calculated from velocity measurements in the inlet pipe. Flow out of the settling chamber was calculated from water-level measurements in the settling chamber. Outlet flow was assumed to be equal to flow out of the settling chamber.The influent (inlet) sample was collected from a creased flat plate mounted below the storm grate. The effluent (outlet) sample was collected from the perforated pipe draining the filter-media chamber. The 15 flow-weighted samples were collected by automated sampling equipment. Two refrigerated samplers equipped with peristaltic pumps and Teflon-lined sample tubing collected the influent and effluent samples in four 10-L glass jars. Composite samples were processed for analysis only if at least two subsamples were collected during increasing flow, two subsamples during decreasing flow, and one near the peak flow. Samples were transported to the Wisconsin State Laboratory of Hygiene (WSLH), where they were analyzed for a total of 68 constituents, including solids, nutrients, trace metals, and polycyclic aromatic hydrocarbons (PAH's). All constituents tested at the WSLH, along with their abbreviations, detection limits, and method used, are listed in tables 1 and 2 . The Microtox toxicity screening procedure (Azur Environmental Inc., Carlsbad, Calif.) was performed on all 15 influent and effluent samples. This rapid procedure involves a marine bioluminescence bacteria (Vibrio fischeri); samples having greater toxicity are indicated by less light output. Particle-size analysis was performed on all samples using a Coulter Counter Multisizer II (Beckman Coulter Inc., Fullerton, Calif.). Both Microtox and particle-size analysis were done at the University of Alabama, Birmingham, Environmental Engineering Laboratory. Loads were computed as the product of the event-mean concentration and total stormflow volume, thus the removal performance of the device was measured by comparing differences in constituent mass into and out of the device. All computations and statistical analyses were done with SAS statistical software (1988).

\section{EVALUATION OF MULTI-CHAMBERED TREATMENT TRAIN EFFICIENCY}

\section{Water Quantity}

Fifteen storms, occurring from April 29 through September 8, 1996, were monitored and sampled. Rainfall amounts for these storms ranged from 0.45 to 3.48 $\mathrm{cm}$. Calculations based on the delineated drainage area indicate that total stormwater volumes for the storms ranged from 1.96 to $14.9 \mathrm{~m}^{3}$. The actual quantity of water passing through the MCTT was 1.72 to $9.10 \mathrm{~m}^{3}$. None of the storms resulted in surcharge of the MCTT. On average, 87 percent of the rainfall resulted in direct runoff to the MCTT. The remaining rainfall volume may have been lost in interception storage, through cracks in the aged pavement surface, or through joint leaks between the grit chamber and the main settling chamber. 
Table 1. Aggregate water-quality characteristics and inorganic constituents analyzed for Multi-Chambered Treatment Train study, Milwaukee, Wis.

[mg/L, milligrams per liter; $\mu \mathrm{g} / \mathrm{L}$, micrograms per liter]

\begin{tabular}{|c|c|c|c|c|}
\hline Constituent & Abbreviation & Units & $\begin{array}{c}\text { Limit of } \\
\text { Detection }\end{array}$ & Method ${ }^{1}$ \\
\hline \multicolumn{5}{|l|}{ Aggregate Characteristics } \\
\hline Alkalinity, total & Alk. & $\mathrm{mg} / \mathrm{L}$ as $\mathrm{CaCO}_{3}$ & 5 & SM 2320B \\
\hline Biochemical oxygen demand & BOD & $\mathrm{mg} / \mathrm{L}$ & 3 & SM 5210B \\
\hline Chemical oxygen demand & COD & $\mathrm{mg} / \mathrm{L}$ & 5 & EPA 410.4 \\
\hline Color & Color (PU) & Plat.-Cobalt & 1 & SM 2120B \\
\hline $\mathrm{pH}$ & $\mathrm{pH}$ & Standard Units & 0.1 & SM4500B \\
\hline Specific conductance & $\mathrm{SC}$ & $\mu \mathrm{s} / \mathrm{cm}$ & $?$ & SM2510B \\
\hline Total dissolved solids & TDS & $\mathrm{mg} / \mathrm{L}$ & 5 & SM2540C \\
\hline Total suspended solids & TSS & $\mathrm{mg} / \mathrm{L}$ & 5 & SM2540D \\
\hline Turbidity & Turbid. & NTU & .05 & SM3120B \\
\hline Volatile suspended solids & VSS & $\mathrm{mg} / \mathrm{L}$ & 5 & SM2540F \\
\hline \multicolumn{5}{|l|}{ Nutrients } \\
\hline Ammonium as $\mathrm{N}$ & $\mathrm{NH}_{4}$ & $\mathrm{mg} / \mathrm{L}$ as $\mathrm{N}$ & .027 & $\mathrm{SM} 4500 \mathrm{H}$ \\
\hline Nitrate + nitrite as $\mathrm{N}$ & $\mathrm{NO}_{3}$ & $\mathrm{mg} / \mathrm{L}$ as $\mathrm{N}$ & .02 & SM4500F \\
\hline Dissolved phosphorus & DP & $\mathrm{mg} / \mathrm{L}$ as $\mathrm{P}$ & .002 & SM4500PF \\
\hline Total phosphorus & $\mathrm{TP}$ & $\mathrm{mg} / \mathrm{L}$ as $\mathrm{P}$ & .008 & SM4500PB \\
\hline \multicolumn{5}{|l|}{ Major ions } \\
\hline Total calcium & $\mathrm{Ca}$ & $\mathrm{mg} / \mathrm{L}$ & 1 & SM3111B \\
\hline Dissolved calcium & $\mathrm{Ca}$ & $\mathrm{mg} / \mathrm{L}$ & 1 & SM3111B \\
\hline Chloride & $\mathrm{Cl}$ & $\mathrm{mg} / \mathrm{L}$ & 1 & SM4500CL \\
\hline Dissolved magnesium & $\mathrm{Mg}$ & $\mathrm{mg} / \mathrm{L}$ & 1 & SM3111B \\
\hline Total magnesium & $\mathrm{Mg}$ & $\mathrm{mg} / \mathrm{L}$ & 1 & SM3120B \\
\hline Sulfate & $\mathrm{SO}_{4}$ & $\mathrm{mg} / \mathrm{L}$ & 5 & $\mathrm{SM} 4500 \mathrm{SO} 4$ \\
\hline \multicolumn{5}{|l|}{ Metals } \\
\hline Dissolved cadmium & $\mathrm{Cd}$ & $\mu \mathrm{g} / \mathrm{L}$ & .02 & SM3113B \\
\hline Total cadmium & $\mathrm{Cd}$ & $\mu \mathrm{g} / \mathrm{L}$ & .04 & EPA 200.9 \\
\hline Dissolved chromium & $\mathrm{Cr}$ & $\mu \mathrm{g} / \mathrm{L}$ & .5 & SM3113B \\
\hline Total chromium & $\mathrm{Cr}$ & $\mu \mathrm{g} / \mathrm{L}$ & 1 & EPA 200.9 \\
\hline Dissolved copper & $\mathrm{Cu}$ & $\mu \mathrm{g} / \mathrm{L}$ & .7 & SM3113B \\
\hline Total copper & $\mathrm{Cu}$ & $\mu \mathrm{g} / \mathrm{L}$ & 1 & EPA 200.9 \\
\hline Dissolved lead & $\mathrm{Pb}$ & $\mu \mathrm{g} / \mathrm{L}$ & .4 & SM3113B \\
\hline Total lead & $\mathrm{Pb}$ & $\mu \mathrm{g} / \mathrm{L}$ & .8 & EPA 200.9 \\
\hline Dissolved zinc & $\mathrm{Zn}$ & $\mu \mathrm{g} / \mathrm{L}$ & 8 & SM3113B \\
\hline Total zinc & $\mathrm{Zn}$ & $\mu \mathrm{g} / \mathrm{L}$ & 19 & EPA 200.9 \\
\hline
\end{tabular}

IEPA (1979); and SM, Standard Methods, American Public Health Association and others, 1989. 
Table 2. Organic constituents analyzed for Multi-Chambered Treatment Train study, Milwaukee, Wis.

[mg/L, milligrams per liter; $\mu \mathrm{g} / \mathrm{L}$, micrograms per liter; $\mathrm{PAH}$, polycyclic aromatic hydrocarbon; -, none]

\begin{tabular}{|c|c|c|c|c|}
\hline Parameter & Abbreviation & Units & Limit of Detection & Method ${ }^{\top}$ \\
\hline Dissolved organic carbon & DOC & $\mathrm{mg} / \mathrm{L}$ as $\mathrm{C}$ & 1 & SM5310 \\
\hline Total organic carbon & TOC & $\mathrm{mg} / \mathrm{L}$ as $\mathrm{C}$ & 1 & SM5311 \\
\hline Sum of total PAH's ${ }^{2}$ & ТPAH & $\mu \mathrm{g} / \mathrm{L}$ & 0.47 & SW8310 \\
\hline Acenaphthene & N/A & $\mu \mathrm{g} / \mathrm{L}$ & .048 & SW8310 \\
\hline Acenaphthylene & - & $\mu \mathrm{g} / \mathrm{L}$ & .044 & SW8310 \\
\hline Anthracene & - & $\mu \mathrm{g} / \mathrm{L}$ & .015 & SW8310 \\
\hline Benz $[a]$ anthracene & - & $\mu \mathrm{g} / \mathrm{L}$ & .059 & SW8310 \\
\hline Benzo[a]pyrene & - & $\mu \mathrm{g} / \mathrm{L}$ & .041 & SW8310 \\
\hline Benzo $[b]$ fluoranthene & - & $\mu \mathrm{g} / \mathrm{L}$ & .073 & SW8310 \\
\hline Benzo $[g, h, i]$ perylene & - & $\mu \mathrm{g} / \mathrm{L}$ & .05 & SW8310 \\
\hline Benzo $[k]$ fluoranthene & - & $\mu \mathrm{g} / \mathrm{L}$ & .059 & SW8310 \\
\hline Chrysene & - & $\mu \mathrm{g} / \mathrm{L}$ & .03 & SW8310 \\
\hline Dibenz $[a, h]$ anthracene & - & $\mu \mathrm{g} / \mathrm{L}$ & .019 & SW8310 \\
\hline Fluoranthene & - & $\mu \mathrm{g} / \mathrm{L}$ & .098 & SW8310 \\
\hline Fluorene & - & $\mu \mathrm{g} / \mathrm{L}$ & .12 & SW8310 \\
\hline Indeno $[1,2,3-c, d]$ pyrene & - & $\mu \mathrm{g} / \mathrm{L}$ & .078 & SW8310 \\
\hline Naphthalene & - & $\mu \mathrm{g} / \mathrm{L}$ & .054 & SW8310 \\
\hline Phenanthrene & - & $\mu \mathrm{g} / \mathrm{L}$ & .035 & SW8310 \\
\hline Pyrene & - & $\mu \mathrm{g} / \mathrm{L}$ & .063 & SW8310 \\
\hline
\end{tabular}

${ }^{1}$ SM, Standard Methods, American Public Health Association and others, 1989; and U.S. Environmental Protection Agency (1996) solid-waste method.

${ }^{2}$ Sum of total PAH's includes the sum of all 16 species of total PAH.

Compared to historical precipitation records, the depths of rainfall for these 15 storms were larger than average (fig. 2). This may be due to the short period that the MCTT was monitored, which included mainly warmweather rainstorms. The historical record includes precipitation from the entire year (from intense summer thunderstorms, long duration fall and spring rainfall, and snowfall). Long-term records (National Oceanic and Atmospheric Administration, 1997) show only 20 percent of Milwaukee storms are greater than $1.3 \mathrm{~cm}$ in precipitation, whereas during the period of study, approximately half of the storms were greater than 1.3 $\mathrm{cm}$. Therefore, in terms of rainfall amounts, the studyperiod events may be considered a rigorous test of the system. The fact that none of the storm-runoff amounts exceeded the design capacity, even though the largest amounts were expected to, was due to inaccurate delineation of the drainage area at the design phase and resultant overdesign of the unit.

\section{Concentration Summary Statistics}

Summaries of the inorganic and organic concentration data for the inflow and outflow samples are given in tables 3 and 4 and in appendix 1, and a summary of the load data and removal efficiencies of the MCTT is given in appendix 2 . All samples were collected on a volume-weighted basis; hence, the concentrations reported here are event-mean concentrations. The constituent concentrations in the runoff entering the unit were characteristic of stormwater quality found in previous studies (U.S. Environmental Protection Agency, 1983; Ellis, 1986; Bannerman and others, 1983, 1993, 1996). The data sets were tested for normality/log-normality using the Shapiro-Wilk statistic (SAS, 1988). This procedure produces a test statistic for the null hypothesis that the input data values are a random sample from a normal or transformed-normal distribution. In general, inorganic as well as organic constituent concentrations were found to be log-normally distributed. Of the 68 constituents measured in the influent, 21 were normally distributed and 47 were log-normally distributed $(\alpha<0.05)$. This test should be interpreted with caution, however, because of its low power when applied to the sample size of 10-15 observations. The log-normal distributions are consistent with the findings of others (U.S. Environmental Protection Agency, 1983; DiToro, 1984). 


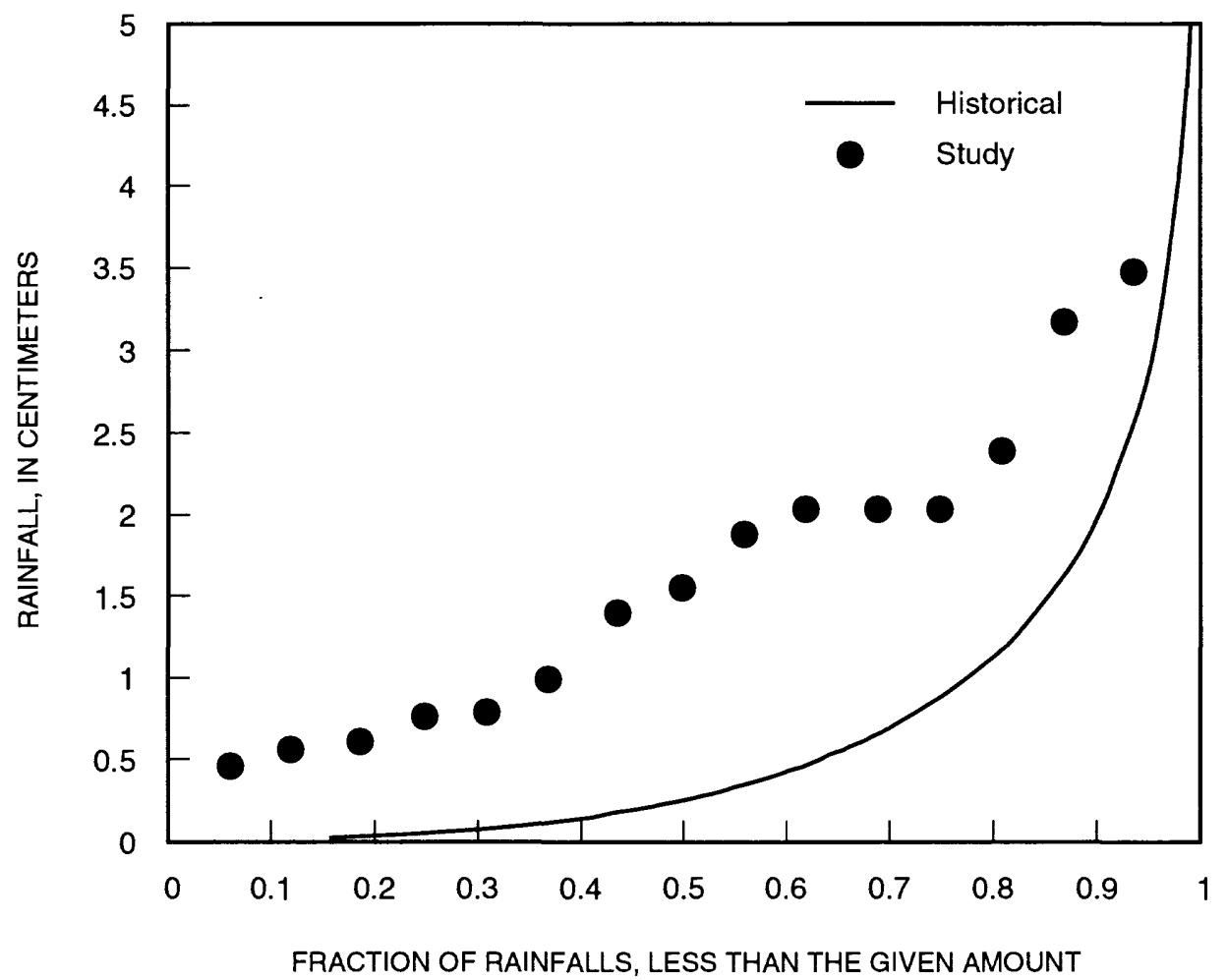

Figure 2. Cumulative rainfall distributions for the study period and historical rainfall records (1948-92) for Milwaukee, Wis.

Influent samples generally had detectable concentrations of most constituents tested. The exception was dissolved zinc $(\mathrm{Zn})$ and the dissolved fractions of 15 of the 16 PAH's, which rarely were detectable. The one dissolved PAH that was consistently measurable in the influent was phenanthrene (median $=0.1 \mu \mathrm{g} / \mathrm{L}$ ).

In the effluent water, all dissolved and total PAH concentrations were below detection limits. In addition, total suspended solids (TSS), volatile suspended solids (VSS), dissolved cadmium (Cd), dissolved lead $(\mathrm{Pb})$, dissolved $\mathrm{Zn}$ and total $\mathrm{Zn}$ were generally below detection limits in the effluent samples. The preponderance of nondetectable values in effluent samples made the determination of normality problematic. Having effluent values reported as "less than" for a constituent also made the exact calculation of removal efficiencies impossible. In those cases, removal efficiencies were estimated using one half of the detection limit as the concentration of the effluent.

The nonparametric two-sided Wilcoxon rank-sum test (SAS, 1988) was applied to the influent and effluent concentrations of all constituents, the null hypothesis being that the distributions of the influent and effluent concentrations are the same. Constituents with signifi- cant differences $(\alpha=0.05)$ are noted in tables 3 and 4 . A paired statistical test comparing individual storms was not used because, during any given storm, the water exiting the device will not be the same water that entered the device because of the permanent storage volume and hydraulic residence time in the settling tank. Influent and effluent concentrations of constituents that were not found to be significantly different were either soluble constituents that are generally considered conservative (for example, chloride) or constituents that have the potential to be generated within the tank (for example, ammonia). Because influent and effluent concentrations of some constituents (for example, dissolved PAH's) frequently were below detection limits, significant changes in concentrations were indeterminable.

\section{Water-Quality Characteristics}

Concentrations of total suspended solids (TSS) in influent ranged widely, from 79 to $1,050 \mathrm{mg} / \mathrm{L}$; median concentration was $232 \mathrm{mg} / \mathrm{L}$ (table 3 , appendix 1). As stated previously, most of the effluent TSS concentra- 
Table 3. Inorganic influent and effluent minimum, maximum, and median event-mean concentration values for the monitored storms $(n=15)$ at the Multi-Chambered Treatment Train in Milwaukee, Wis.

[BOD, biochemical oxygen demand; COD, chemical oxygen demand; TDS, total dissolved solids; TSS, total suspended solids; VSS, volatile suspended solids; $\mathrm{NH}^{4}$, ammonium, as $\mathrm{N} ; \mathrm{NO}^{3}$, nitrate plus nitrate; $\mathrm{Ca}$, calcium; $\mathrm{Mg}$, magnesium; $\mathrm{Cl}$, chloride; $\mathrm{SO}_{4}$, sulfate; $\mathrm{Cd}, \mathrm{cadmium} ; \mathrm{Cr}$, chromium; $\mathrm{Cu}$, copper; $\mathrm{Pb}$, lead; $\mathrm{Zn}$, zinc; TOC, All units in milligrams per liter unless otherwise noted. Bold font identifies constituents for which influent concentrations are significantly different $(\alpha=0.05)$ from effluent concentrations using a nonparametric two-sided Wilcoxon rank-sum test.]

\begin{tabular}{|c|c|c|c|c|c|c|}
\hline \multirow{2}{*}{ Characteristic or constituent } & \multicolumn{3}{|c|}{ Influent } & \multicolumn{3}{|c|}{ Effluent } \\
\hline & Minimum & Maximum & Median & Minimum & Maximum & Median \\
\hline \multicolumn{7}{|l|}{ Aggregate characteristic } \\
\hline Turbidity (NTU) & 9.3 & 100 & 41 & 0.7 & 10 & 2.6 \\
\hline Color (PU) & 10 & 70 & 30 & 5.0 & 25 & 15 \\
\hline BOD & 8.8 & 51 & 15 & $<3.0$ & 9.2 & $<3$ \\
\hline COD & 52 & 260 & 115 & $<5.0$ & 33 & 13 \\
\hline pH (SIC) & 6.8 & 8.1 & 7.2 & 7.5 & 8.1 & 7.8 \\
\hline Alkalinity & 20 & 58 & 40 & 51 & 122 & 82 \\
\hline TDS & 164 & 5,930 & 634 & 320 & 3,070 & 885 \\
\hline TSS & 79 & 1,050 & 232 & $<5.0$ & 18 & $<5.0$ \\
\hline VSS & 17 & 154 & 52 & $<5.0$ & 12 & $<5.0$ \\
\hline \multicolumn{7}{|l|}{ Nutrients } \\
\hline $\mathrm{NH}_{4}$ as $\mathrm{N}$ & $<.027$ & .258 & .051 & $<.027$ & .115 & .062 \\
\hline $\mathrm{NO}_{2}+\mathrm{NO}_{3}$ as $\mathrm{N}$ & .180 & 1.36 & .353 & .074 & .463 & .273 \\
\hline Phosphorus, total & .101 & .440 & .262 & .014 & .088 & .023 \\
\hline Phosphorus, dissolved & $<.002$ & .040 & .0025 & .002 & .0016 & .002 \\
\hline \multicolumn{7}{|l|}{ Major Ions } \\
\hline Ca, total & 18 & 210 & 43 & 19 & 66 & 32 \\
\hline $\mathrm{Ca}$, dissolved & 8.3 & 45 & 16 & 18 & 68 & 31 \\
\hline Mg, total & 4.0 & 100 & 14 & 2.1 & 13 & 3.4 \\
\hline Mg, dissolved & .4 & 1.2 & .82 & 2.0 & 13 & 3.4 \\
\hline $\mathrm{Cl}$ & 57 & 3,560 & 302 & 100 & 1820 & 427 \\
\hline $\mathrm{SO}_{4}$ & 10 & 58 & 19 & 16 & 47 & 27 \\
\hline \multicolumn{7}{|l|}{ Metals } \\
\hline Cd,dissolved $(\mu \mathrm{g} / \mathrm{L})$ & .03 & 1.1 & .22 & $<.02$ & .97 & .05 \\
\hline $\mathrm{Cr}$, dissolved $(\mu \mathrm{g} / \mathrm{L})$ & $<.5$ & 2.0 & .8 & $<.5$ & 3.4 & .8 \\
\hline $\mathrm{Cu}$, dissolved $(\mu \mathrm{g} / \mathrm{L})$ & 1.7 & 12 & 4.4 & $<.7$ & 5.7 & 1.4 \\
\hline Pb, dissolved $(\mu \mathrm{g} / \mathrm{L})$ & $<.4$ & 7.6 & .9 & $<.4$ & 1.3 & $<.4$ \\
\hline Zn, dissolved $(\mu \mathrm{g} / \mathrm{L})$ & $<8$ & 38 & $<8$ & $<8$ & 22 & $<8$ \\
\hline Cd-total $(\mu \mathrm{g} / \mathrm{L})$ & .48 & 3.7 & 1.5 & $<.04$ & 1.0 & .10 \\
\hline $\mathrm{Cr}$, total $(\mu \mathrm{g} / \mathrm{L})$ & 3 & 14 & 6 & $<1$ & 18 & $<1$ \\
\hline $\mathrm{Cu}$, total $(\mu \mathrm{g} / \mathrm{L})$ & 11 & 58 & 32 & 2 & 8 & 3 \\
\hline Pb, total $(\mu \mathrm{g} / \mathrm{L})$ & 16 & 72 & 48 & $<.8$ & 3.9 & 1.8 \\
\hline $\mathrm{Zn}$, total $(\mu \mathrm{g} / \mathrm{L})$ & 55 & 250 & 150 & $<19$ & 53 & $<19$ \\
\hline \multicolumn{7}{|l|}{ Organics } \\
\hline Total organic carbon & 2.2 & 20 & 7.9 & 2.1 & 11 & 4.4 \\
\hline Dissolved organic carbon & 2.1 & 17 & 6.8 & 2.0 & 9.5 & 4.1 \\
\hline $\begin{array}{l}\text { Sum of total polycycli } \\
\text { aromatic hydrocarbon }\end{array}$ & 2.9 & 23 & 8.3 & $<.47$ & $<.89$ & $<.89$ \\
\hline
\end{tabular}


Table 4. Dissolved and total influent minimum, maximum, and median event-mean concentrations of polycyclic aromatic hydrocarbons for the monitored storms $(n=15)$ at the Multi-Chambered Treatment Train in Milwaukee, Wis.

[Concentrations in micrograms per liter. All effluent concentrations were below detection limits.]

\begin{tabular}{|c|c|c|c|}
\hline Constituent & Minimum ${ }^{1}$ & Maximum & Median \\
\hline \multicolumn{4}{|l|}{ Dissolved PAH species } \\
\hline Acenaphthene & $<0.048$ & $<0.048$ & $<0.048$ \\
\hline Acenaphthylene & $<.044$ & $<.044$ & $<.044$ \\
\hline Anthracene & $<.015$ & .026 & $<.015$ \\
\hline Benz $[a]$ anthracene & $<.059$ & .23 & $<.059$ \\
\hline Benzo $[a]$ pyrene & $<.041$ & .38 & $<.041$ \\
\hline Benzo $[b]$ fluoranthene & $<.073$ & .54 & $<.073$ \\
\hline Benzo $[g, h, i]$ perylene & $<.05$ & .38 & $<.05$ \\
\hline Benzo $[k]$ fluoranthene & $<.059$ & .24 & $<.059$ \\
\hline Chrysene & $<.03$ & .52 & $<.03$ \\
\hline $\operatorname{Dibenz}[a, h]$ anthracene & $<.019$ & .038 & $<.019$ \\
\hline Fluoranthene & $<.098$ & 1.1 & $<.098$ \\
\hline Fluorene & $<.12$ & $<.12$ & $<.12$ \\
\hline Indeno $[1,2,3-c, d]$ pyrene & $<.078$ & .39 & $<.078$ \\
\hline Naphthalene & $<.054$ & $<.054$ & $<.054$ \\
\hline Phenanthrene & $<.035$ & .35 & .105 \\
\hline Pyrene & $<.063$ & .79 & $<.063$ \\
\hline \multicolumn{4}{|l|}{ Total PAH species } \\
\hline Acenaphthene & $<.048$ & .23 & $<.048$ \\
\hline Acenaphthylene & $<.044$ & $<.044$ & $<.044$ \\
\hline Anthracene & $<.015$ & .34 & .101 \\
\hline Benz $[a]$ anthracene & $<.24$ & 1.4 & .5 \\
\hline Benzo $[a]$ pyrene & $<.4$ & 1.6 & .55 \\
\hline Benzo[b]fluoranthene & $<.23$ & 2 & .77 \\
\hline Benzo $[g, h, i]$ perylene & $<.64$ & 1.4 & .53 \\
\hline Benzo $[k]$ fluoranthene & $<.46$ & 1 & .31 \\
\hline Chrysene & $<.26$ & 2.1 & .8 \\
\hline Dibenz $[a, h]$ anthracene & $<.24$ & 1.4 & .5 \\
\hline Fluoranthene & .51 & 5.1 & 1.75 \\
\hline Fluorene & $<.12$ & .38 & $<.12$ \\
\hline Indeno $[1,2,3-c, d]$ pyrene & $<.8$ & 1.4 & .48 \\
\hline Naphthalene & $<.054$ & $<.054$ & $<.054$ \\
\hline Phenanthrene & .12 & 2.8 & .71 \\
\hline Pyrene & .47 & 3.2 & 1.3 \\
\hline
\end{tabular}

${ }^{1}$ Digestion of samples for total analysis resulted in higher detection limits. In addition, detection limits varied during the period of study. Bold font identifies constituents in which influent concentrations are significantly different $(\alpha=0.05)$ from effluent concentrations using a nonparametric two-sided Wilcoxon rank-sum test. 
tions were below detection limit ( 8 out of 14). The highest concentration of TSS observed in the effluent was only $18 \mathrm{mg} / \mathrm{L}$. Because most effluent TSS values were below detection limit, it was difficult to determine if any discernible relation existed between influent and effluent concentrations. The influent TSS concentrations from all 15 storms exceeded Wisconsin's discharge limit of $30 \mathrm{mg} / \mathrm{L}$ (Wisconsin Administrative Code NR $210,1997)$. The cumulative load of TSS to the unit for the 15 consecutive storms was $18.3 \mathrm{~kg}$ (appendix 2). The amount of TSS in the effluent was estimated to be only $0.30 \mathrm{~kg}$, making the overall removal efficiency greater than 98 percent. Pitt and others (1997) reported a lower overall TSS removal of 83 percent in their pilotscale testing. In examining concentrations at intermediate points, they found that most of the TSS was removed in the settling chamber.

Influent volatile suspended solids (VSS) ranged from 17 to $154 \mathrm{mg} / \mathrm{L}$; median concentration was $52 \mathrm{mg} / \mathrm{L}$. The VSS concentrations averaged 21 percent of TSS in the influent, an indication that most of the particulate material entering the unit was inorganic. On a cumulative mass basis, the VSS influent load was 17 percent of the influent TSS load. Effluent VSS concentrations ranged from less than 5 to $12 \mathrm{mg} / \mathrm{L} ; 58$ percent of the samples were below the detection limit. The overall load reduction of VSS (>94 percent) was similar to that for TSS. The influent biochemical oxygen demand (BOD) concentrations ranged from 8.8 to $51 \mathrm{mg} / \mathrm{L}$. Only one sample had a BOD concentration that would exceed the Wisconsin discharge limit of 30 $\mathrm{mg} / \mathrm{L}$ (Wisconsin Administrative Code NR 210, 1997). Again, most BOD in effluent samples (58 percent) was below the detection limit. The estimate of overall removal efficiency for $\mathrm{BOD}$ was 82 percent or greater. The chemical oxygen demand (COD) influent and effluent concentrations (median $=115$ and 13 , respectively) were considerably greater than the BOD concentrations. Influent VSS concentrations were well correlated with both BOD and COD concentrations ( $\mathrm{r}=0.62$ and 0.82 , respectively), confirming the organic nature of this solid material. The average ratio of BOD to $\mathrm{COD}$ was 0.15 in the influent, suggesting that this organic material was highly refractory. The unit removed 86 percent of the total COD load.

Total dissolved solids (TDS) in influent samples had a median concentration of $634 \mathrm{mg} / \mathrm{L}$ and a range of 164 to $5,930 \mathrm{mg} / \mathrm{L}$. The source of the high dissolved solids in samples collected during the middle of the study period was road salt stored within the drainage area. This salt resulted in a load of dissolved solids to the unit that was more than 4.5 times the particulate (suspended solids) load for the period of study. The relative loads of the three aggregate solids characteristics are illustrated in figure 3 . (Note that the $y$-axis is plotted on a $\log$ scale.)

\section{Major lons}

Total calcium $(\mathrm{Ca})$ had the greatest influent concentrations (median $=43 \mathrm{mg} / \mathrm{L}$ ) of the reported cations (table 3, appendix 1). Though not directly measured, the ionic balance and high chloride concentrations suggest that sodium and/or potassium were most likely the dominant cations. Dissolved Ca concentrations generally made up half of the total $\mathrm{Ca}$ in the influent. Total magnesium $(\mathrm{Mg})$ concentrations followed a similar stormto-storm pattern as total calcium concentrations, but at about one-third the concentration (median $=14 \mathrm{mg} / \mathrm{L}$ ). Dissolved Mg generally made up only 10 percent of the total $\mathrm{Mg}$ in the influent.

In effluent, total $\mathrm{Ca}$ concentrations were always less than those in the influent, although the median values differed by only $4.5 \mathrm{mg} / \mathrm{L}$. Somewhat surprisingly, the dissolved $\mathrm{Ca}$ concentrations in the effluent were consistently greater than the influent concentrations, suggesting either dissolution of some of the influent particulate $\mathrm{Ca}$ and (or) addition of $\mathrm{Ca}$ ions to the stormwater from the unit itself (that is, concrete walls of the catch basin and main tank). Magnesium behaved similarly, with dissolved $\mathrm{Mg}$ concentrations in effluent greater than those in influent. On a load basis, the unit removed 55 and 85 percent of the total $\mathrm{Ca}$ and $\mathrm{Mg}$, respectively (appendix 2). The increase in dissolved $\mathrm{Ca}$ and $\mathrm{Mg}$ concentrations resulted in negative efficiencies for these analytes ( -62 and -340 , respectively). The effluent loads of both dissolved $\mathrm{Ca}$ and $\mathrm{Mg}$ were equal to their respective total loads, implying that the $\mathrm{Ca}$ and $\mathrm{Mg}$ leaving the unit was virtually all in the dissolved phase.

Chloride $(\mathrm{Cl})$ was by far the dominant anion in all the samples (median influent and effluent $=302$ and $427 \mathrm{mg} / \mathrm{L}$, respectively). Again, this was a result of road salt being stored within the drainage area during the study period. Both influent and effluent concentrations during the 15 storms are shown in figure 4 . Placement of the road salt onsite occurred between the fourth and fifth storms, and this is clearly evident in the sharp increase in $\mathrm{Cl}$ concentrations in figure 4. Peak effluent 


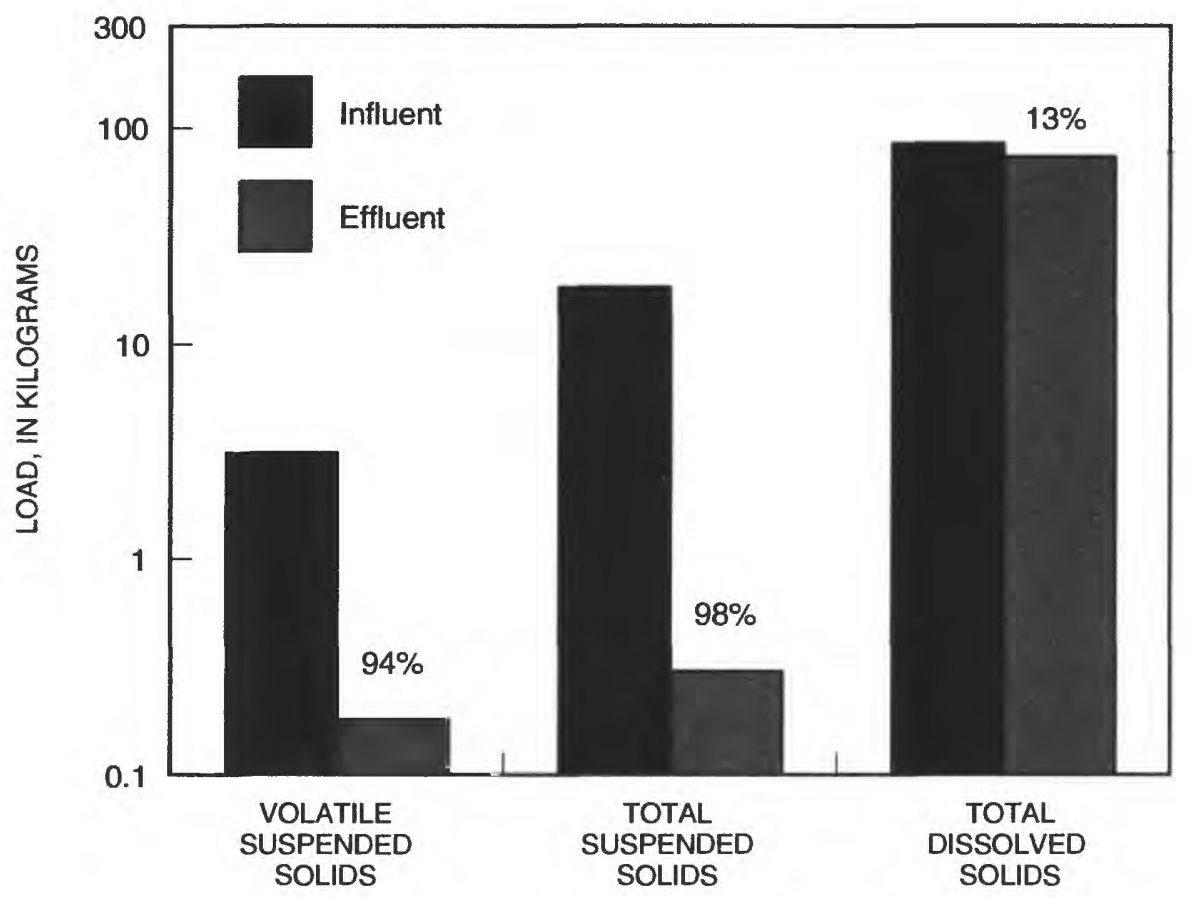

Figure 3. Total influent and effluent loads for volatile suspended solids, total suspended solids, and total dissolved solids accumulated over the entire rating period at the Multi-Chambered Treatment Train in Milwaukee, Wis. (Removal efficiencies, in percent, are noted above the effluent load bars.)

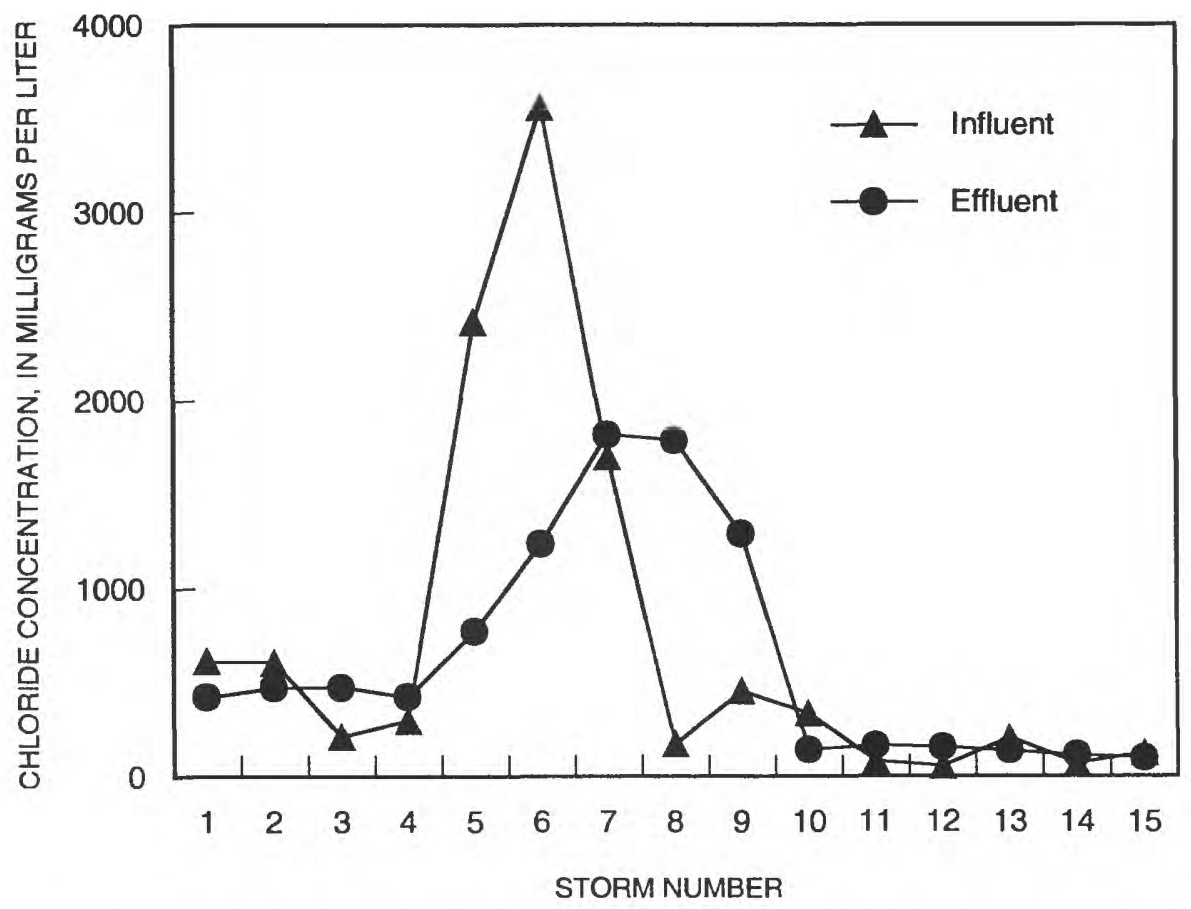

Figure 4. Event-mean concentrations of chloride in influent and effluent for the 15 monitored storms, Multi-Chambered Treatment Train study, in Milwaukee, Wis. 


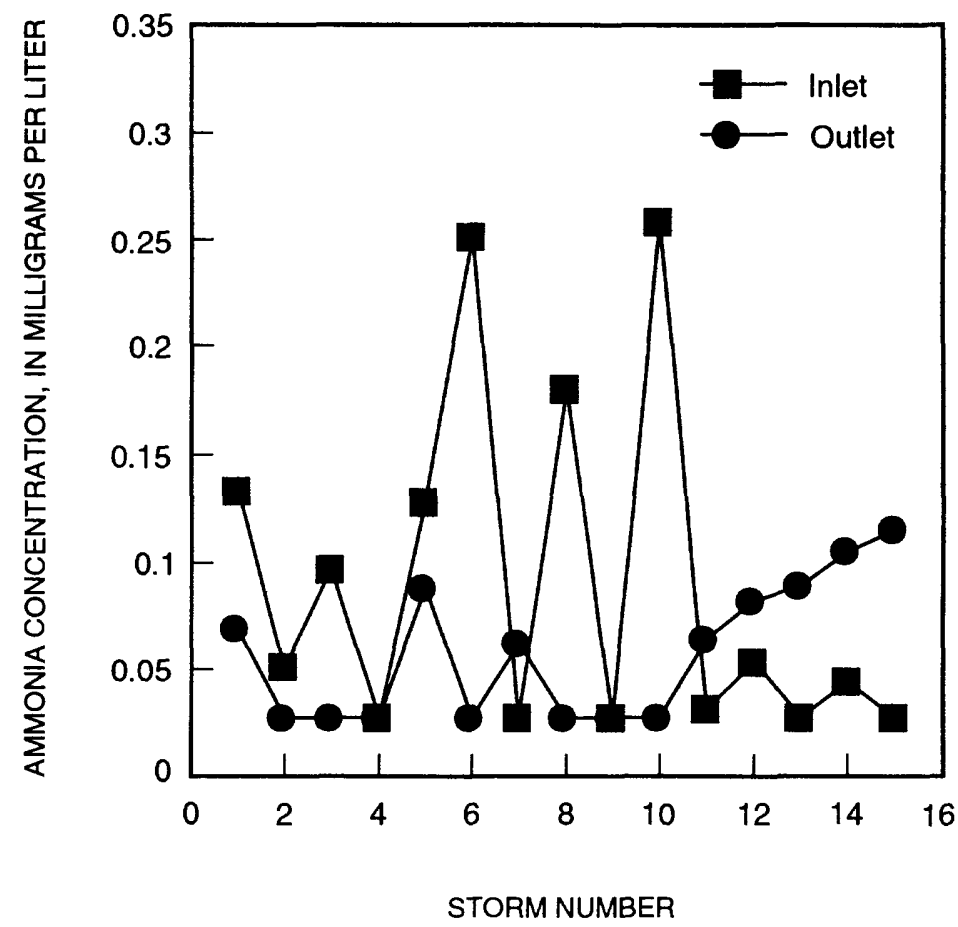

Figure 5. Event-mean concentrations of ammonium in influent and effluent for the 15 monitored storms, Multi-Chambered Treatment Train study, in Milwaukee, Wis.

concentration, however, was substantially less than the peak influent concentration. This attenuation of maximum effluent concentrations was due to dilution of the influent waters with previously stored water in the settling tank. Although $\mathrm{Cl}$ is generally considered to be a conservative constituent, the difference between influent and effluent loads of 20 percent suggests that the unit did remove a portion of the $\mathrm{Cl}$.

Alkalinity concentrations were considerably less than $\mathrm{Cl}$ concentrations (median influent and effluent concentrations $=40$ and $82 \mathrm{mg} / \mathrm{L}$, respectively). On an equivalence basis, alkalinity (as bicarbonate) closely tracked Ca concentrations and increased as the water passed through the unit, again pointing to an addition/dissolution of calcium carbonate in the unit.

\section{Nutrients}

The median nitrate $\left(\mathrm{NO}_{3}\right)$ concentrations in the influent and effluent were 0.35 and $0.27 \mathrm{mg} / \mathrm{L}$, respectively (table 3 ). Removal efficiency of this mobile nitrogen species was 32 percent (appendix 2). Ammonium $\left(\mathrm{NH}_{4}\right)$ concentrations were often considerably less than $\mathrm{NO}_{3}$ concentrations in the influent and the effluent (appendix 1). The removal rate for ammonium (47 per- cent) was somewhat greater than that for $\mathrm{NO}_{3}$, although the rate decreased over the study period because of a steady rise in effluent concentrations over the last five storms (fig. 5). This rise of ammonium concentrations in effluent indicates that the settling-chamber contents may become anaerobic as sediments begin to accumulate and reduced species are subsequently released within the unit.

Influent total phosphorus $(\mathrm{P})$ ranged from 0.10 to $0.44 \mathrm{mg} / \mathrm{L}$; the median was $0.26 \mathrm{mg} / \mathrm{L}$. Effluent concentrations were generally an order of magnitude less than influent concentrations (median $=0.02 \mathrm{mg} / \mathrm{L}$ ), resulting in a high overall removal efficiency of 88 percent. Dissolved $\mathrm{P}$ was consistently less than 10 percent of the total $P$ in the influent and the effluent samples. Dissolved $\mathrm{P}$ removal efficiency ( 78 percent), although somewhat less than total $\mathrm{P}$ removal, was still substantial.

\section{Metals}

Influent metals concentrations were characteristic of values previously observed in stormwater runoff in Wisconsin (Bannerman and others, 1996). Median total recoverable metal concentrations, in increasing order, 
were $\mathrm{Cd}(1.5 \mu \mathrm{g} / \mathrm{L}), \mathrm{Cr}(6 \mu \mathrm{g} / \mathrm{L}), \mathrm{Cu}(32 \mu \mathrm{g} / \mathrm{L}), \mathrm{Pb}$ $(48 \mu \mathrm{g} / \mathrm{L})$, and $\mathrm{Zn}(150 \mu \mathrm{g} / \mathrm{L})$ (table 3$)$. The total recoverable metal concentrations in effluent followed a similar order of increasing concentration, except that lead and copper were reversed (appendix 1). Concentrations of all total recoverable metals in effluent were generally an order of magnitude less than concentrations in influent. A comparison of total recoverable metals concentrations in influent to Wisconsin acute toxicity criteria for warmwater sport fisheries (Wisconsin Admininstrative Code, NR105, 1997) showed that $\mathrm{Cu}$ exceeded the criteria in 15 of 15 samples, $\mathrm{Pb}$ in 7 of 15 samples, and $\mathrm{Zn}$ in 14 of 15 samples. In contrast, no total recoverable metal concentrations in effluent exceeded metal-toxicity criteria.

Removal efficiencies of the MCTT were substantial for all the total recoverable metals, ranging from 78 percent for $\mathrm{Cr}$ to 96 percent for $\mathrm{Pb}$ (appendix 2). Because most of the total recoverable metal concentrations were in the particulate form, the physical removal of particulates may be occurring in all three chambers of the unit, although the bulk of the particulates (associated with the suspended solids) was most likely being removed in the settling chamber. MCTT performance data collected by Pitt and others (1997) for TSS and unfiltered metals also suggests this, although for $\mathrm{Cd}$ and $\mathrm{Cu}$, efficiencies were substantially less than those for the unit used in this study. This difference may have been due to several factors, such as a different mixture of filter media, the different concentration ranges of $\mathrm{Cd}$ and $\mathrm{Cu}$, and differences in the proportion of these metals in the dissolved form, which are less effectively removed than those in particulate form.

Concentrations of dissolved metals in the influent to the MCTT followed the order of $\mathrm{Cd}<\mathrm{Cr}<\mathrm{Pb}<\mathrm{Cu}$ $<\mathrm{Zn}$. The concentrations in effluent appeared to follow a similar order, although a full characterization of metals concentrations is again difficult because of many below detection limit. With the exception of $\mathrm{Cr}$, removal efficiencies of dissolved metals ranged from 66 to 78 percent, somewhat less than their respective total metal removals efficiencies (appendix 2). Because concentrations in effluent were generally found below detection limits, actual removals may have been greater, especially for $\mathrm{Cd}, \mathrm{Pb}$, and $\mathrm{Zn}$. The order of removal efficiencies of dissolved metals was $\mathrm{Cr}<\mathrm{Cd}<\mathrm{Zn}<\mathrm{Cu}$ $<\mathrm{Pb}$. The removal of the dissolved phase of these metals most likely occurred in the sand/peat/carbon filter chamber. A similar order of "affinity" in peat materials was noted by Pakarinen and others (1981) for $\mathrm{Cu}, \mathrm{Pb}$, and $\mathrm{Zn}$. They did not describe $\mathrm{Cd}$ and $\mathrm{Cr}$ affinities. Dissolved chromium, which has a higher valence and requires time to reach exchange equilibrium, had virtually no removal efficiency ( -3.3 percent) (Aho and Tummavuori, 1984).

Although the concentrations of metals generally were greatly reduced by the treatment of the MCTT, the proportion of metal in the dissolved phase generally increased. In the influent samples, the average ratio of dissolved metal to total metal concentrations ranged from 3 percent for $\mathrm{Pb}$ to 19 percent for $\mathrm{Cu}$. In the effluent samples, the proportion of the dissolved phase in the total recoverable metal was higher ranging from 20 percent for $\mathrm{Cd}$ to 80 percent for $\mathrm{Cr}$.

\section{Polycyclic Aromatic Hydrocarbons}

Detectable concentrations of 12 of the 16 total polycyclic aromatic hydrocarbon (PAH) species were typically found in influent samples to the MCTT (table 4, appendix 1). The four species that were below detection limits in more than 50 percent of the samples were total acenaphthylene, acenaphthene, fluorene, and naphthalene. Concentrations of total fluoranthene and pyrene were consistently double or more than the concentrations of other PAH species, with median concentrations of 1.8 and $1.4 \mu \mathrm{g} / \mathrm{L}$, respectively. The sum of total PAH concentrations for all 16 species $(\Sigma$ total $\mathrm{PAH}$ ) in the influent samples ranged from 2.9 to $23 \mu \mathrm{g} / \mathrm{L}$. The median $\Sigma$ total PAH concentration was $8.3 \mu \mathrm{g} / \mathrm{L}$, considerably less than what was reported by Steuer and others (1997) for parking lots. All of the 15 influent samples exceeded the Wisconsin human cancer criterion of $0.1 \mu \mathrm{g} / \mathrm{L}$ (Wisconsin Administrative Code, NR 105, 1997) for the class of streams draining this area. This criterion is based on dermal contact and the consumption of warmwater sport fish taken from these waters.

In the influent, the $\Sigma$ dissolved PAH averaged 14 percent of the $\Sigma$ total PAH. The average percentage may be less because the dissolved fractions were commonly reported as less than detection limits, and actual concentrations are unknown. The only dissolved $\mathrm{PAH}$ species in the influent that was consistently reported above the detection limit was phenanthrene (median $=0.1 \mu \mathrm{g} / \mathrm{L}$ ). The dissolved PAH concentrations were also consistently above the Wisconsin human cancer criterion of $0.1 \mu \mathrm{g} / \mathrm{L}$. 
Little interpretation can be made from the effluent PAH data because, without exception, all values were reported as less than the detection limit. Consequently, all PAH removal efficiencies are conservative estimates of actual removal rates. Efficiencies of individual total PAH's ranged from $>53$ percent for total fluorene to $>98$ percent for total phenanthrene, and for 11 of the total PAH's, efficiencies were 90 percent (appendix 2). The removal efficiencies of the dissolved PAH fractions ranged from $>22$ percent (dibenzanthracene) to $>86$ percent (phenanthrene) and were consistently lower than the removal efficiencies for total PAH's. This finding does not necessarily suggest a lower removal efficiency of dissolved $\mathrm{PAH}$ fractions; the lower efficiencies may be an artifact due to a preponderance of "less-than" values or concentrations approaching the detection limit.

Because most of the PAH's were found in the particulate fraction, most of the removal probably occurred in the settling chamber, consistent with the findings of Pitt and others (1997). In addition, peat materials, such as those found in the filter chamber, have been shown to be effective in removing oily material (Mathavan and Viraraghavan, 1989).

\section{Microtox Results}

Microtox-assay results, reported as gamma values, are computed as the amount of light lost from exposed fluorescent bacteria (as compared to a laboratory control) divided by the amount of light remaining. The larger the value of gamma, the greater the detrimental effect the sample has on the test microbes. Influentsample gamma values from 15-minute assays ranged from 0.02 to 0.49 ; the median was 0.12 (appendix 3 ). In contrast, all effluent samples yielded negative gamma values (median $=-0.17$ ), suggesting that the effluent water was a better medium for microbial growth than the laboratory control water. Without exception, Microtox gamma values were less in effluent samples than influent samples, a strong indication that toxicity was reduced by MCTT treatment. There was however, little indication of any simple relation (linear regression) between Microtox gamma values for influent and concentrations of any single constituent.

\section{Particle-Size Distribution}

The particle-size data were summarized by averaging the 15 influent and effluent cumulative distributions of those data (fig. 6). Each trace on this plot represents the average percentage of particles less than the given size for each measured particle-size fraction. Most influent and effluent particles were in the silt-size fraction. Somewhat surprising was the fact that no appreciable shift in the particle-size distribution was observed between the influent and effluent particle sizes. One might expect a selective removal of the larger particles and subsequent decrease in the average particle size as the water passed through the filter media. The findings here, however, suggest that the mean particle size, or $\mathrm{D}_{50}$, actually increased from $18 \mu \mathrm{m}$ in the influent water to $28 \mu \mathrm{m}$ in the treated effluent water; thus, the unit may not have been selective in the size of particles it removed. Another possibility is that large particulate materials were indeed removed in the settling chamber, but escaped sand fines from the filter media were later reintroduced. Because no samples were collected between the settling and filter chambers, the proportion of the suspended-solids treatment that can be attributed to each section of the unit cannot be determined. Another indication that the filter chamber can potentially lose particles is reported by Pitt and others (1997), who noted a slight increase in TSS concentrations as the water passed through the filter tank of their pilot-scale unit. Therefore, the unit may be selectively removing larger particles but, coincidently, may be adding similar particles from the filter-media material, resulting in little change in the distributions. It is emphasized, however, that even though the particle-size distribution influent remained similar, the overall removal rate of the particulate material by the unit was 98 percent of the influent suspended-solids load.

\section{SUMMARY}

The MCTT treated all the stormwater that drained to the unit for the 15 storms monitored. The actual quantity of water passing through the MCTT ranged from 1.7 to $8.9 \mathrm{~m}^{3}$ for individual storms and was, on average, 87 percent of the rainfall volume. High reduction efficiencies were found for all particulate-associated constituents, such as TSS ( 98 percent), total $\mathrm{P}$ ( 88 percent), and total $\mathrm{Zn}$ (91 percent). Dissolved fractions were removed at substantial but somewhat lower rates (TDS, 13 percent; dissolved $\mathrm{P}, 78$ percent; dissolved $\mathrm{Zn}$, 


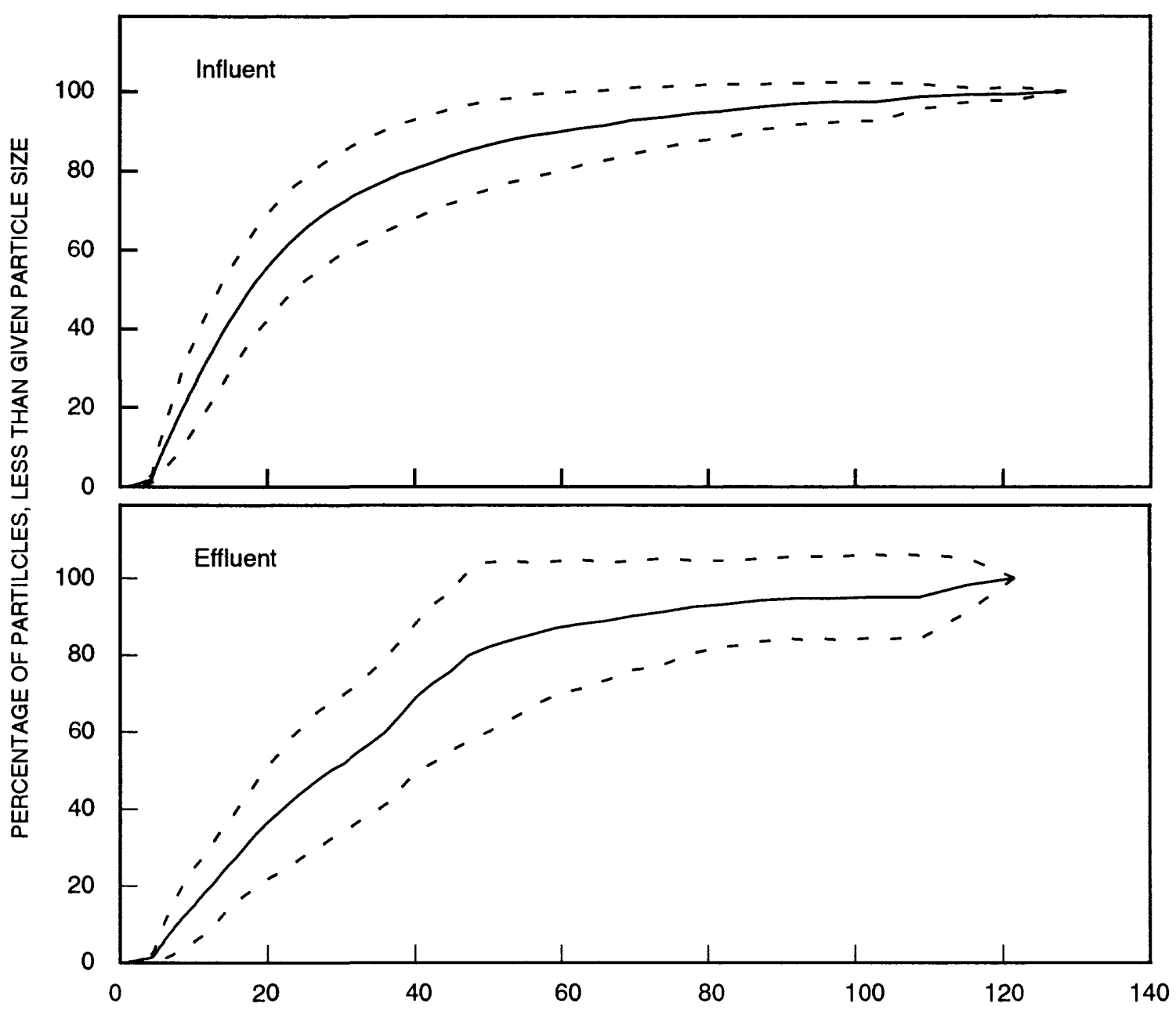

PARTICLE SIZE, IN MICROMETERS

Figure 6. Average influent and effluent particle-size distributions for the 15 monitored storms in the Multi-Chambered Treatment Train, in Milwaukee, Wisconsin. (The dotted lines represent $+/-1$ standard deviation.)

68 percent). The TDS load, which was composed mainly of road salt, was four times the load of TSS. Increases of $\mathrm{Ca}, \mathrm{Mg}$, and alkalinity were attributed to dissolution or leaching of the cement from the MCTT tanks. In addition, $\mathrm{NH}_{4}$ began to rise slowly over the latter part of the study, presumably because of aneaerobic sediment buildup in the settling chamber. No appreciable shift was seen between influent and effluent particle-size distribution.

\section{REFERENCES CITED}

Aho, M., and Tummavuori, J., 1984, The effect of experimental conditions on ion exchange properties of sphagnum peat: Suo, v. 35, p. 47-53.
American Public Health Association, 1989, Standard Methods for the Examination of Water and Wastewater, $17^{\text {th }}$ ed.: Washington, D.C. [variously paginated].

Bannerman, R.T., Baun, K., Bohn, M., Hughes, P.E., and Graczyk, D.A., 1983, Evaluation of urban nonpoint source pollution management in Milwaukee County, Wisconsin-Vol. 1. for U.S. Environmental Protection Agency, Region V: Wisconsin Department of Natural Resources Publication PB 84-114164 [variously paginated].

Bannerman, R.T., Legg, A.D., and Greb, S.R., 1996, Quality of Wisconsin stormwater, 1989-94: U.S. Geological Survey Open-File Report 96-458, 26 p.

Bannerman, R.T., Owens, D.B., Dodds, R.B., and Hornewer, N.J., 1993, Sources of pollutants in Wisconsin stormwater: Water Science Technology, v. 28, no. 3-5, p. 241-259. 
DiToro, D.M., 1984, Probability model of stream quality due to runoff: Journal of Environmental Engineering, ASCE, v. 110, no. 3, p. 607-628.

Ellis, J.B., 1986, Pollutional aspects of urban runoff, Torno, H.C., Marsalek, J., and Desbordes, M., eds., Urban runoff pollution: Berlin, New York, Springer Verlag, p. 1-36.

Mathavan, G.N., and Viraraghavan, T., 1989, Use of peat in the treatment of oily waters: Water, Air, and Soil Pollution, v. 45 , p. $17-25$.

National Oceanic and Atmospheric Administration, 1997, National Climatic Data Center: Milwaukee General Mitchell Airport Precipitation records 1948-1996 [variously paginated].

Pakarinen, P., Tolonen, K., and Soveri, J., 1981, Distribution of trace metals and sulfur in the surface waters of Finnish raised bogs in Proceedings, Sixth International Peat Congress, Duluth, Minnesota, USA: Eveleth, Minn., Fisher, p. 645-648.

Pitt, R., Robertson, B., Barron, P., Ayyoubi, A., and Clark, S., 1997, Stormwater treatment at critical areas. V. 1-The Multi-Chambered Treatment Train (MCTT), University of Alabama-Birmingham: Edison, N.J. Prepared for U.S. Environmental Protection Agency Wet-Weather
Flow Management Program, National Risk Management Research Laboratory. 08837, $169 \mathrm{p}$.

SAS Institute Inc., 1988, Language guide for personal computers, release $6.03 \mathrm{Ed}$ : Cary, N.C., 558 p.

Steuer, J., Selbig, W., Horner, N., and Prey, J., 1997, Sources of contamination in an urban basin in Marquette, Michigan and an analysis of concentrations, loads, and data quality: U.S. Geological Survey Water-Resources Investigations Report 97-4242, 25 p.

U.S. Environmental Protection Agency, 1997, Test methods for evaluation of solid waste, SW846 (3d ed.): Washington, D.C. [variously paginated].

U.S. Environmental Protection Agency, 1983, Results of the Nationwide Urban Runoff Program, volume 1- final report, Water Planning Division: Washington, D.C., U.S. Environmental Protection Agency NTIS No. PB84-185552 [variously paginated].

U.S. Environmental Protection Agency, 1979, Methods for chemical analysis of water and wastes: U.S. Environmental Protection Agency EPA 600/4-79-020, 460 p.

Wisconsin Administrative Code, 1997, Department of Natural Resources, Environmental Protection General. Chapters NR 100- and 200 [variously paginated]. 



\section{APPENDIXES 1-3}




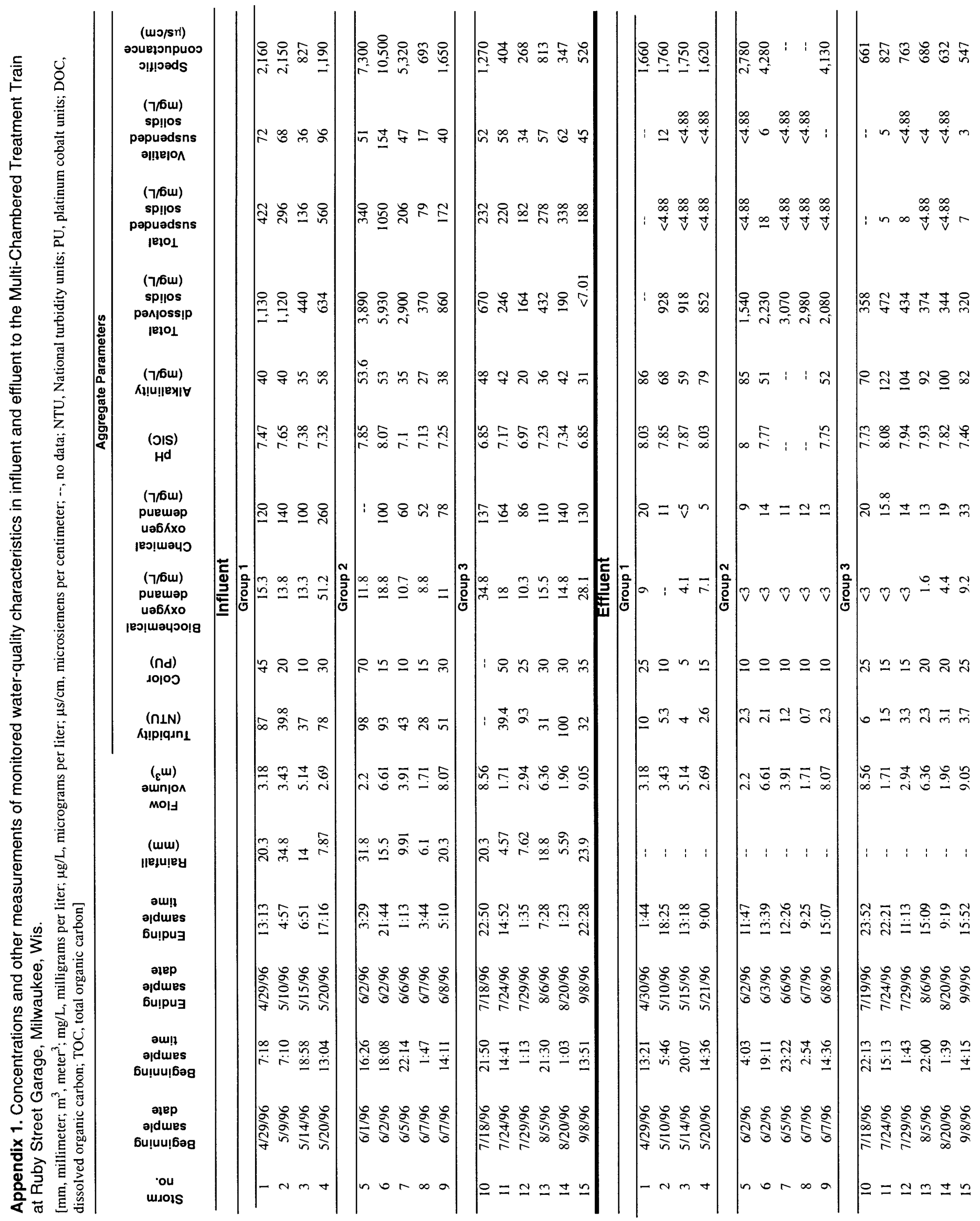




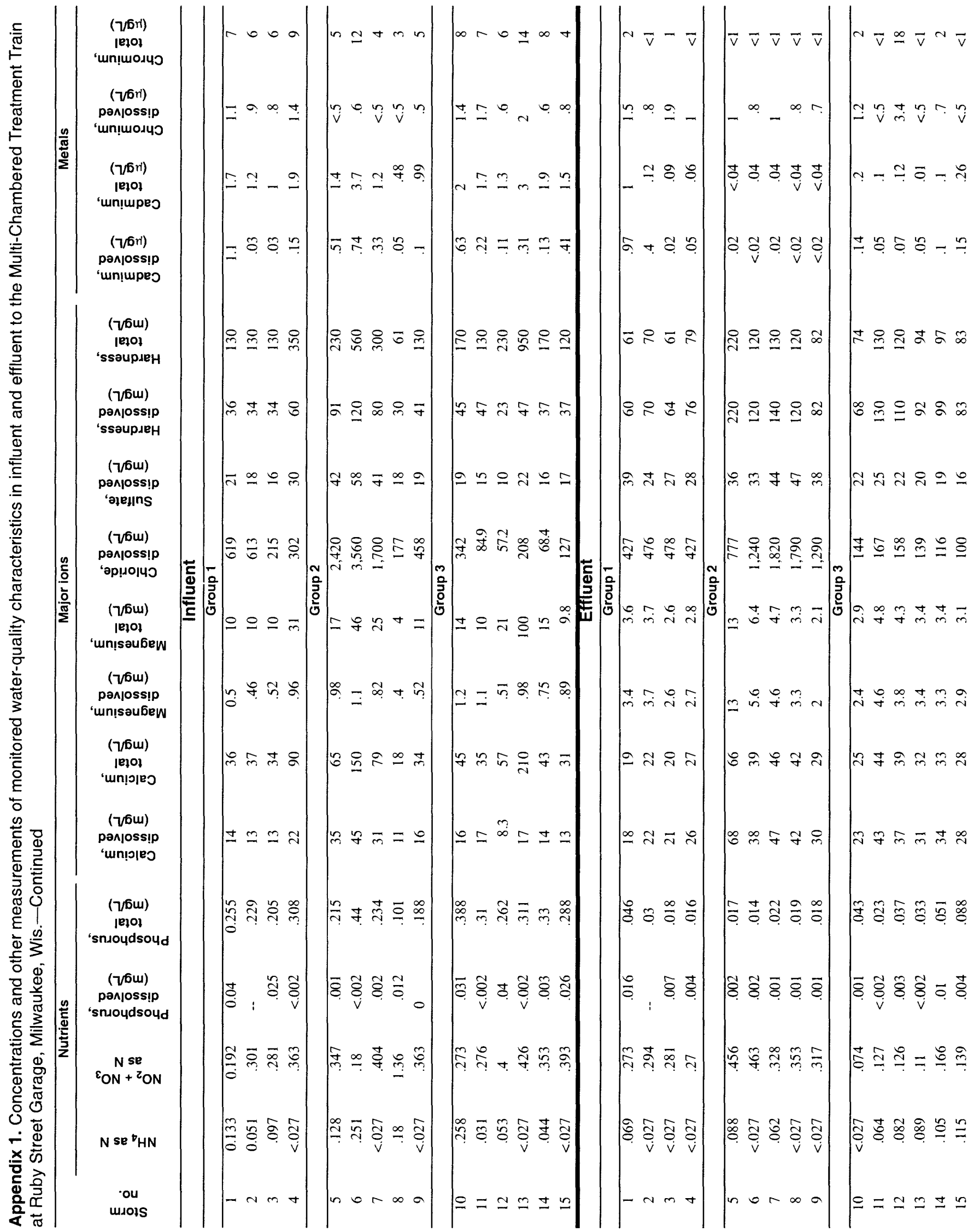




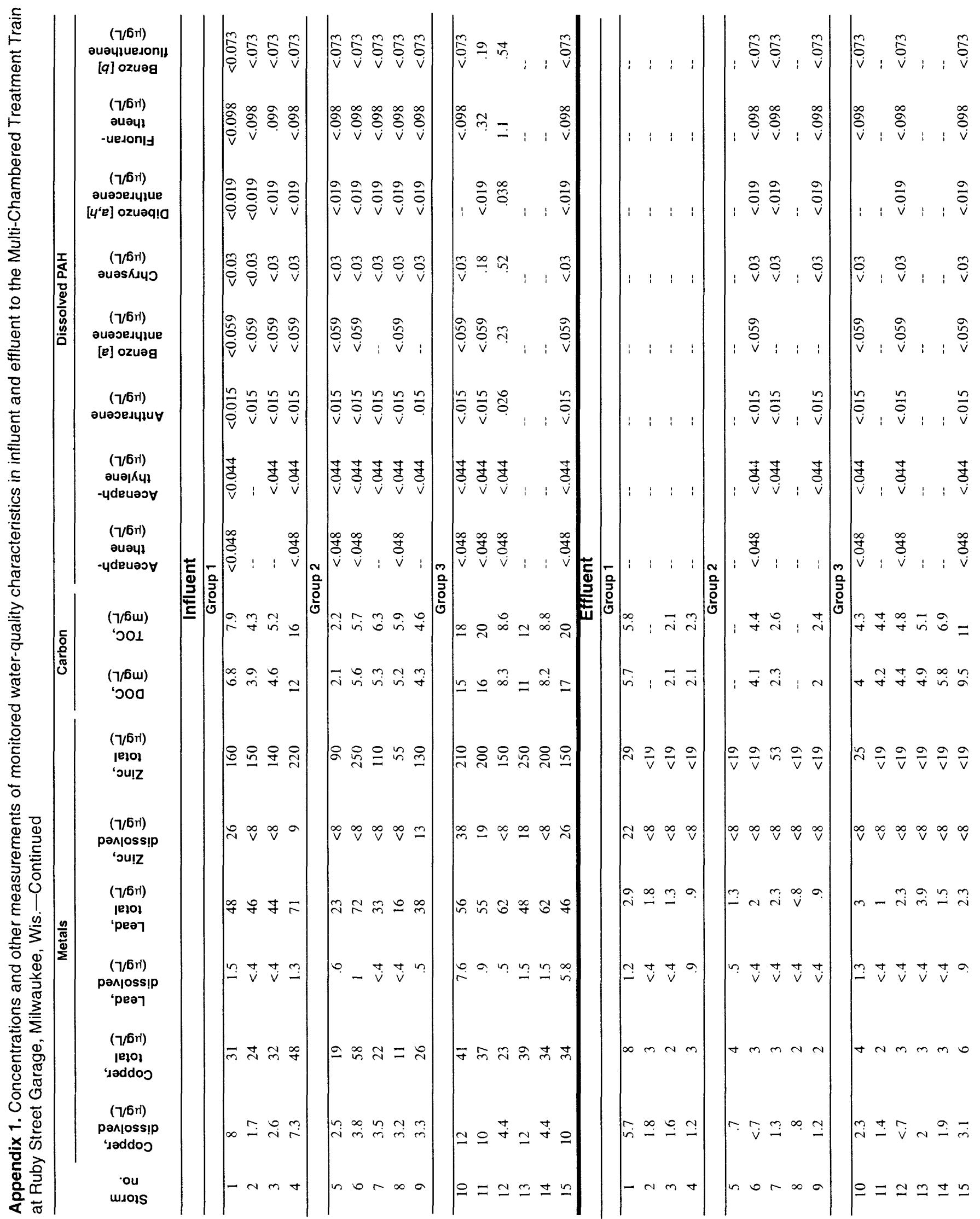




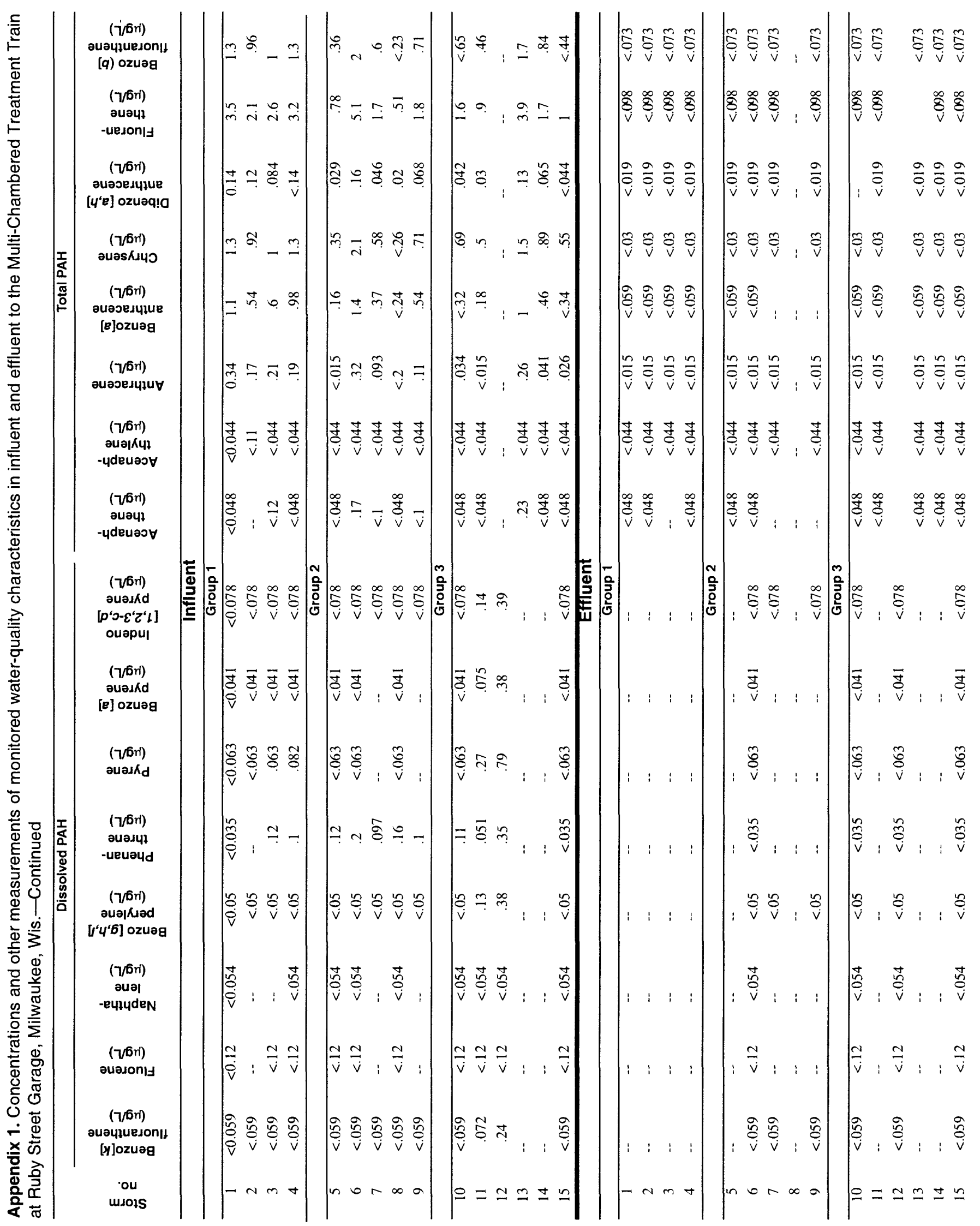




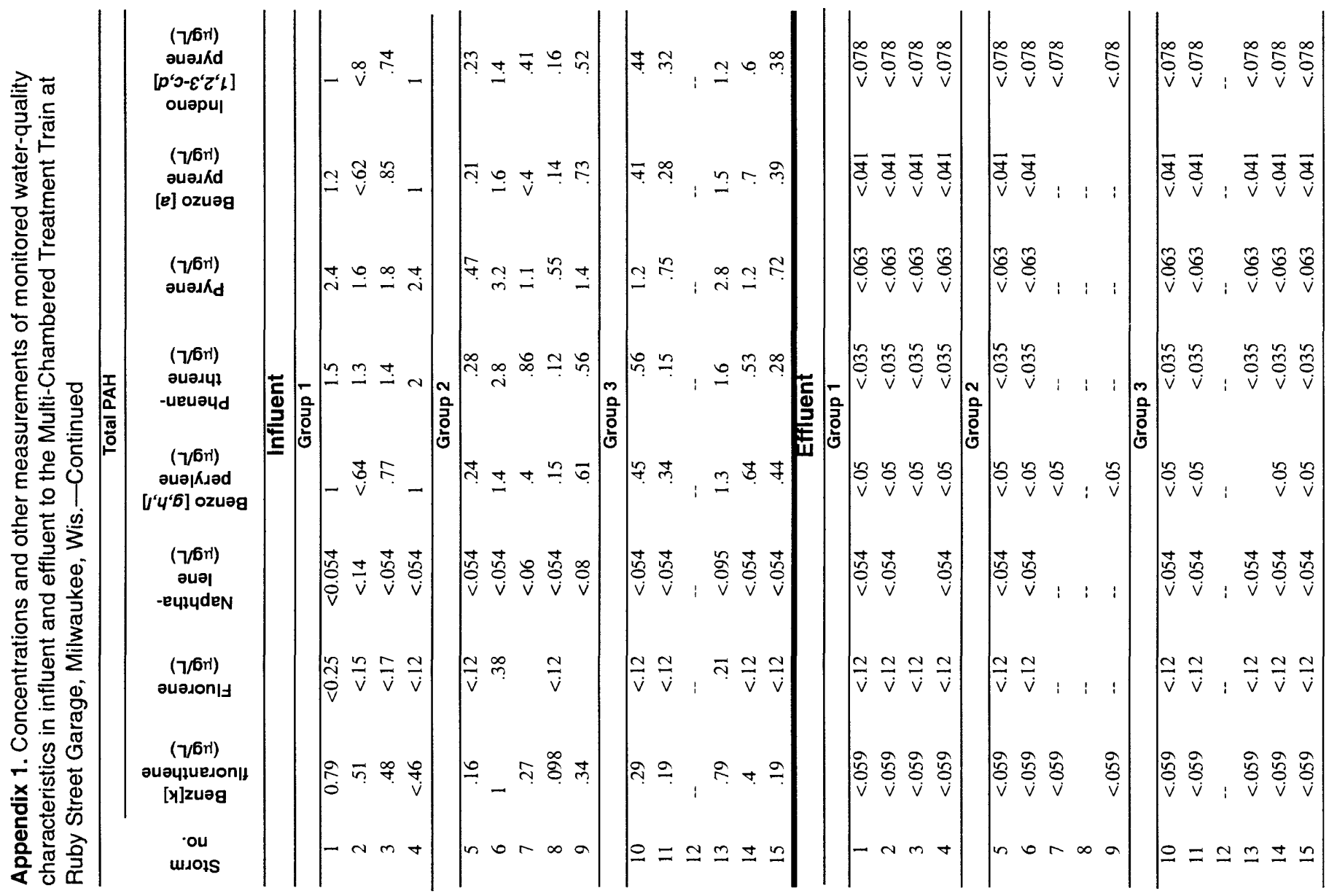




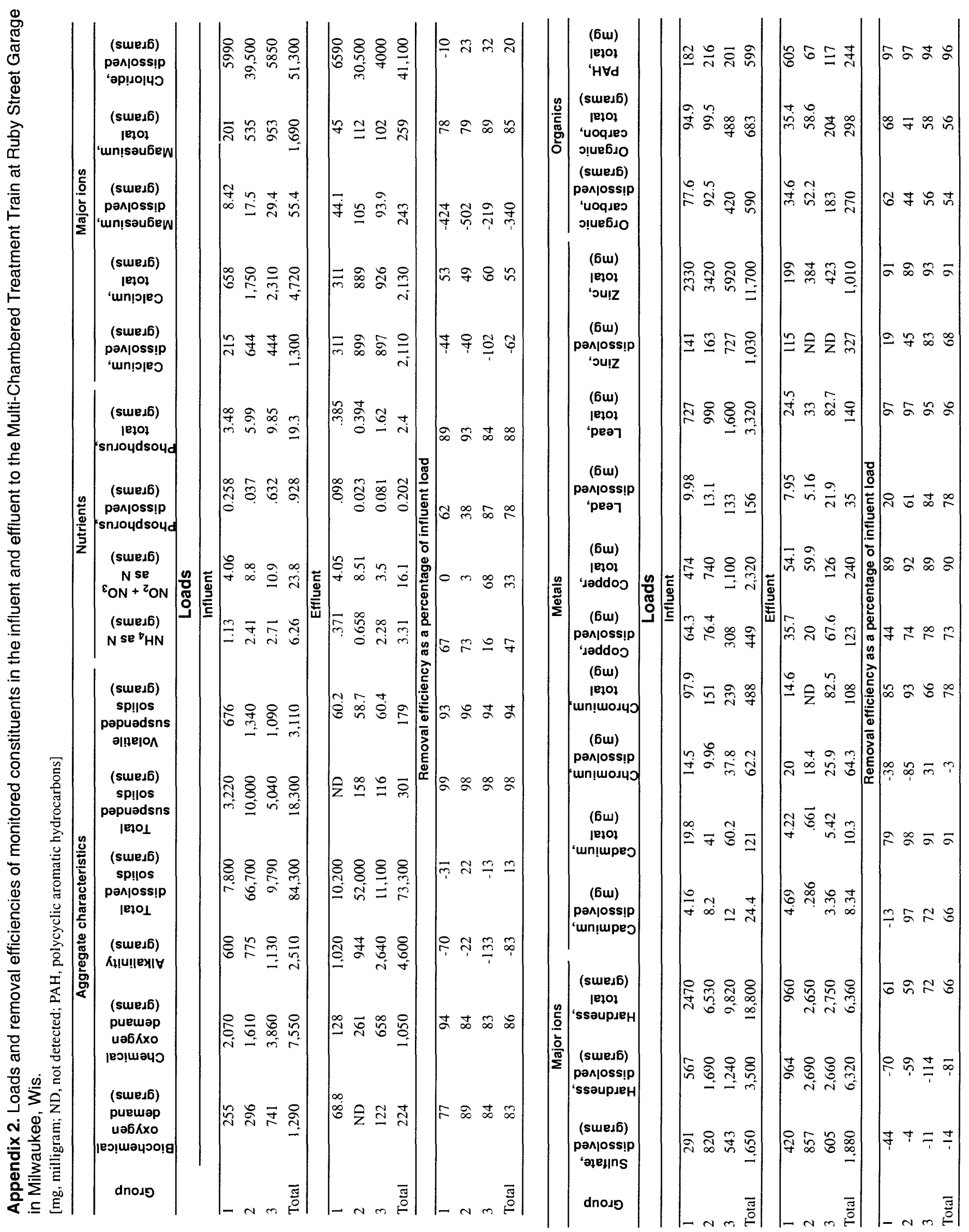


Appendix 3. Results from Microtox analyses of influent and effluent samples at the Multi-Chambered Treatment Train at Ruby St. Garage, Milwaukee, Wis.

\begin{tabular}{cccccc}
\hline & \multicolumn{4}{c}{ Microtox Gamma values } \\
\cline { 2 - 3 } \cline { 5 - 6 } Storm no. & \multicolumn{2}{c}{ Influent } & & \multicolumn{2}{c}{ Effluent } \\
\cline { 2 - 3 } \cline { 5 - 6 } & $\mathbf{5}$ minute & $\mathbf{1 5}$ minute & & $\mathbf{5}$ minute & $\mathbf{1 5}$ minute \\
\hline 1 & 0.26 & 0.34 & & -0.12 & -0.14 \\
3 & .09 & .1 & & -.23 & -.28 \\
4 & .11 & .15 & & -.16 & -.24 \\
5 & .32 & .41 & & -.06 & -.09 \\
6 & .05 & .03 & & -.23 & -.27 \\
7 & .01 & .02 & & -.19 & -.23 \\
8 & .12 & .04 & & -.15 & -.22 \\
9 & .25 & .34 & & -.23 & -.25 \\
10 & -.04 & .02 & & -.25 & -.26 \\
11 & .09 & .09 & -.05 & -.04 \\
12 & .5 & .49 & -.07 & -.17 \\
13 & .24 & .31 & -.02 & -.05 \\
14 & .15 & .17 & -.12 & -.13 \\
15 & .12 & .23 & -.12 & -.12 \\
& .26 & .3 & -.1 & -.13 \\
\hline
\end{tabular}

